ABDIMAS: Jurnal Pengabdian Masyarakat Universitas Merdeka Malang
Vol.7(1) February 2022, 84-93
L-ISSN: 2721-138X e-ISSN: 2548-7159
Uttp://jurnal.unmer.ac.id/index.php/jpkm

\title{
Education on making natural herbal soap made from waste cooking oil
}

\section{Edukasi pembuatan sabun herbal alami berbahan dasar limbah minyak jelantah}

\author{
Rahma Diyan Martha1, Ika Rachutami², Danar Danar ${ }^{3}$ \\ ${ }^{1,2}$ Departemen Farmasi, STIKes Karya Putra Bangsa Tulungagung \\ J. Raya, Tulungagung-Blitar KM 04, Tulungagung, 66291, Indonesia \\ ${ }^{3}$ Departemen Kimia, FMIPA Universitas Negeri Malang \\ Jl. Semarang No. 5, Malang, 65145, Indonesia
}

\begin{abstract}
ARTICLE INFO:
\section{ABSTRACT}

Received: 2021-09-02

Revised: 2021-11-12

Accepted: 2021-12-08

Waste cooking oil (WCO) resulted from the frying process with the same cooking oil repeatedly. The use of used cooking oil can pose a danger to the human body, and the continuous disposal of used cooking oil harms the environment and the sustainability of human life. This problem was found in Wates Village, Sumbergempol District, especially housewives who are also members of the Rukun Makmur $K R P L$ in the village. This community service aims to provide socialization and training (education) in

Keywords: making soap made from used cooking oil. The method used in this activity is lecture and discussion. COVID and posttest are carried out before and after the activity, which is one form of evaluation. The activity results showed that counseling and training on soap making had provided new information and

Housewifes, Soap, Training, Waste cooking oil knowledge to KRPL mothers in Rukun Makmur, Wates Sumbergempol Village, Tulungagung Regency, and provided skills to make soap from used cooking oil. This activity has been able to be followed and carried out well by the participants.
\end{abstract}

(C) 2022 Abdimas: Jurnal Pengabdian Masyarakat Universitas Merdeka Malang This is an open access article distributed under the CC BY-SA 4.0 license (https://creativecommons.org/licenses/by-sa/4.0/)

How to cite: Martha, R. D., Rachutami, I., \& Danar, D. (2020). Education on making natural herbal soap made from waste cooking oil. Abdimas: Jurnal Pengabdian Masyarakat Universitas Merdeka Malang, 7(1), 84-93.

https://doi.org/10.26905/abdimas.v7i1.6054

\section{PENDAHULUAN}

Kabupaten Tulungagung merupakan salah satu Kabupaten yang ada di Jawa Timur, dimana Kabupaten ini berada di antara pegunungan dan sebagian besaradalah persawahan. Melihat keadaan Kabupaten Tulungagung yang Sebagian besar adalah persawahan, masyarakat di Kabupaten Tulungagung bermata pencaharian sebagai petani, salah satunya yaitu Desa Wates Kecamatan Sumbergempol Kabupaten Tulungagung. Selain itu, masyarakat di Kabupaten Tulungagung khususnya di Desa Wates Kecamatan Sumbergempol sebagian besar juga di dominasi oleh ibu rumah tangga dimana yang kesehariannya 


\section{Education on making natural herbal soap made from waste cooking oil}

Rahma Diyan Martha, Ika Rachutami, Danar Danar

bekerja di rumah dan memiliki tanggung jawab atas kebutuhan rumah tangganya. Salah satu kebutuhan yang dibutuhkan oleh ibu rumah tangga adalah minyak goreng.

Minyak goreng adalah minyak hasil pemurnian dari minyak nabati yang digunakan untuk menggoreng makanan. Hampir setiap hari ibu rumah tangga melakukan aktivitas menggoreng makanan di dapur, karena makanan hasil penggorengan yang dikonsumsi tidak melihat dari segi usia, dengan kata lain segala tingkat usia mengkonsumsi makanan hasil penggorengan tersebut (Putra et al, 2016). Belakangan ini ada fenomena yang mungkin tidak disadari oleh masyarakat, sekitar 1,5 tahun kondisi yang memaksa untuk melakukan banyak aktifitas dirumah, tentu saja membuat konsumsi meningkat dan akibatnya limbah rumah tangga menjadi lebih banyak, 2-3 kali konsumsi normal. Salah satu limbah rumah tangga yang mengalami peningkatan signifikan adalah penggunaan minyak goreng.

Minyak goreng terdiri dari dua puluh jenis asam lemak yang berbeda-beda, dengan kata lain tidak ada minyak goreng yang tersusun atas satu jenis asam lemak. Penyusun minyak goreng ini yang menentukan karakteristik dan mutu dari minyak goreng. Menurut Sutiah et al, (2008) karakteristik minyak goreng terdiri dari dua yaitu karakteristik kimia dan karakteristik fisik. Karakteristik kimia meliputi jumlah dan komposisi asam lemak, sedangkan warna, bau, viskositas, titik didih dan bobot jenis tergolong ke dalam karakteristik fisik. Beberapa karakteristik tersebut dapat menentukan mutu dari minyak goreng, diantaranya yaitu komposisi asam lemak dan warna dari minyak goreng (Suroso, 2013). Selain itu, menurut Noriko et al (2012) yang dapat menentukan mutu minyak goreng diantaranya sifat kimia dan stabilitas minyak goreng.

Mutu minyak goreng menentukan minyak goreng itu termasuk ke dalam minyak goreng yang baik atau tidak baik (rusak). Minyak goreng baik merupakan minyak goreng yang terdiri dari perbandingan asam minyak jenuh dan tak jenuh, dimana jumlah asam lemak jenuh lebih sedikit dibandingan dengan asam lemak tak jenuh. Asam lemak jenuh akan semakin berkurang dengan adanya proses penggorengan secara terus-menerus dengan minyak yang sama dan akan menyebabkan nutrisi pada makanan juga akan berkurang (Kusumaningtyas et al, 2018). Dengan demikian minyak tersebut termasuk minyak yang tidak baik (rusak) atau dikenal dengan minyak jelantah.

Minyak jelantah adalah minyak goreng hasil penggorengan yang digunakan secara berulangulang menggunakan minyak goreng yang sama. Penggunaan minyak goreng secara berulang-ulang dapat mempengaruhi kualitas minyak goreng dan nutrisi pada makanan. Sehingga, apabila makanan hasil penggorengan dari minyak jelantah di konsumsi dapat menimbulkan penyakit pada tubuh kita. Permasalahan lain yang dihadapi yaitu pembuangan minyak jelantah di lingkungan secara terusmenerus dapat merusak atau mencemari lingkungan (Pujiati, 2018), hal ini terjadi di Desa Wates yaitu limbah minyak jelantah dibuang begitu saja tanpa adanya pengolahan, Menurut Nane et al (2014) jika minyak jelantah dibuang ke perairan dapat merusak ekosistem yang ada di perairan, contohnya Chemical Oxygen Demind (COD) dan Biological Oxygen Demind (BOD).

Perlu adanya solusi untuk permasalahan yang dihadapi oleh masyarakat terkait limbah minyak jelantah dan adanya usaha supaya limbah minyak jelantah tidak mencemari lingkungan dan perairan. Salah satu cara dengan pengolahan kembali minyak jelantah menjadi suatu produk yang dapat dimanfaatkan oleh masyarakat yang bernilai ekonomis dan pemberdayaan ibu rumah tangga dalam mengolah minyak menjadi produk yang bermanfaat didalam kehidupan sehari-hari (Rahayu et al, 2020 dan Wijaya et al, 2014). Salah satu alternatif dari pemanfaatan minyak jelantah yaitu pembuatan sabun.

Pembuatan sabun merupakan salah satu inovasi yang mudah dilakukan dalam pemanfaatan minyak jelantah. Selain itu, sabun hasil pengolahan minyak jelantah bernilai ekonomis sehingga memiliki potensi untuk dikembangkan dikalangan masyarakat dan dapat menambah sumber penghasilan bagi ibu rumah tangga khususnya di Desa Wates Kecamatan Sumbergempol Kabupaten Tulungagung. 
ABDIMAS: Jurnal Pengabdian Masyarakat Universitas Merdeka Malang

Volume 7, No 1, February 2022: 84-93

Permasalahan lain yang diketahui dari ibu rumah tangga pada kegiatan pengabdian masyarkat ini adalah: (1) Hampir semua peserta menggunakan minyak jelantah untuk mengoreng secara berulangulang; (2) Kurangnya pengetahuan tentang bahaya yang ditimbulkan dengan penggunaan minyak jelantah; (3) Peserta belum mengetahui bahwa minyak jelantah dapat diolah menjadi produk lain yang memiliki nilai ekonomis.

Berdasarkan permasalahan itu, mendorong tim pengabdian masyarakat dengan tujuan, memberikan pengetahuan tentang bahaya minyak jelantah, memberikan ketrampilan membuat olahan dari minyak jelantah atau perlu adanya inovasi dalam pengelolaan limbah minyak goreng dengan melibatkan partisipasi masyarakat. Hal tersebut merupakan dasar mengapa perlu adanya solusi cerdas dalam meningkatkan mutu kesehatan masyarakat. Di bawah ini merupakan kerangka solusi pemecahan masalah terhadap limbah jelantah. Adapun gambar disajikan pada Gambar 1.

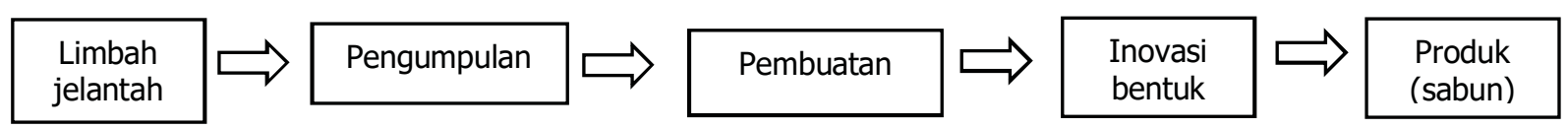

Gambar 1. Alur pemecahan masalah

\section{METODE}

\section{Presentasi dan tanya jawab}

Pelaksanaan kegiatan pengabdian masyarakat dilaksanakan hari Jumat tanggal 02 April 2021 jam 09.00 WIB di salah satu rumah warga di Desa Wates. Pelaksanaan kegiatan ini dimulai dengan metode pendekatan yaitu dalam bentuk ceramah dan tanya jawab. Ceramah dilakukan dari sesi pertama, yaitu sambutan atau perkenalan dari ketua pelaksana dan tim pelaksana, serta penyampaian materi oleh pemateri. Tujuannya adalah memperkenalkan diri kepada peserta dan sebaliknya (menciptakan keakraban) dari awal hingga akhir kegiatan. Selain itu, ceramah disini juga menyampaikan pendahuluan terkait minyak goreng hingga disebut minyak jelantah, dampak dan solusi atau manfaat minyak jelantah, serta penjelasan tentang metode yang akan dipraktikkan di setiap kegiatan pengabdian masyarakat ini. Selain menjelaskan, ketua pelaksana juga memberikan beberapa pertanyaan untuk peserta dan tidak lupa juga dengan memberikan kesempatan peserta untuk bertanya kembali. Tujuan sesi tanya jawab bagi pemateri adalah untuk mengetahui sejauh mana pengetahuan awal tentang pendahuluan ini.

\section{Praktek}

Selanjutnya edukasi pembuatan sabun dari minyak jelantah yang dilakukan oleh para peserta yaitu anggota KRPL Rukun Makmur Desa Wates Sumbergempol. Pembuatan sabun dilakukan terlebih dahulu oleh pemateri dengan memaparkan setiap langkah pembuatan sabun minyak jelantah yang kemudian dapat diikuti oleh para peserta. Para peserta boleh mengajukan pertanyaan di dalam proses pembuatan sabun minyak jelantah. Tujuan diadakannnya praktek secara langsung adalah memberikan ketrampilan kepada peserta dengan harapan peserta dapat membuat sabun secara mandiri dan dapat mengajarkan kepada warga yang lain.

\section{Modul}

Kegiatan pengabdian masyarakat ini menggunakan acuan untuk memberikan gambaran peserta selain dari penjelasan ketua pelaksana atau pemateri yaitu berupa modul. Modul disini berisi tentang definisi minyak goreng dan minyak jelantah, ambang batas pemakaian minyak goreng, pemilihan minyak goreng yang baik, dampak pemakaian minyak jelantah dan solusi atau manfaat yang bisa 


\section{Education on making natural herbal soap made from waste cooking oil}

Rahma Diyan Martha, Ika Rachutami, Danar Danar

dimanfaatkan dari minyak jelantah tersebut, dan lain-lain. Pemberian modul disini memberikan gambaran tentang minyak jelantah, selain dari penjelasan atau pemaparan materi.

\section{Rancangan evaluasi}

Dalam mengevaluasi kegiatan pengabdian masyarakat disini meliputi: Peran aktif peserta selama sesi pertama (kehadiran, absensi serta COVID); kemampuan peserta dalam pembuatan sabun (dengan melihat produk sabun yang dihasilkan dan posttest).

\section{Tahapan pelaksanaan}

Gambar 2 menunjukkan langkah-langkah pelaksanaan pengabdian masyarakat. Pelaksanaan kegiatan pengabdian masyarakat di awali dengan pembukaan dan diakhiri dengan foto bersama setelah kegiatan workshop pembuatan sabun dari minyak jelantah.

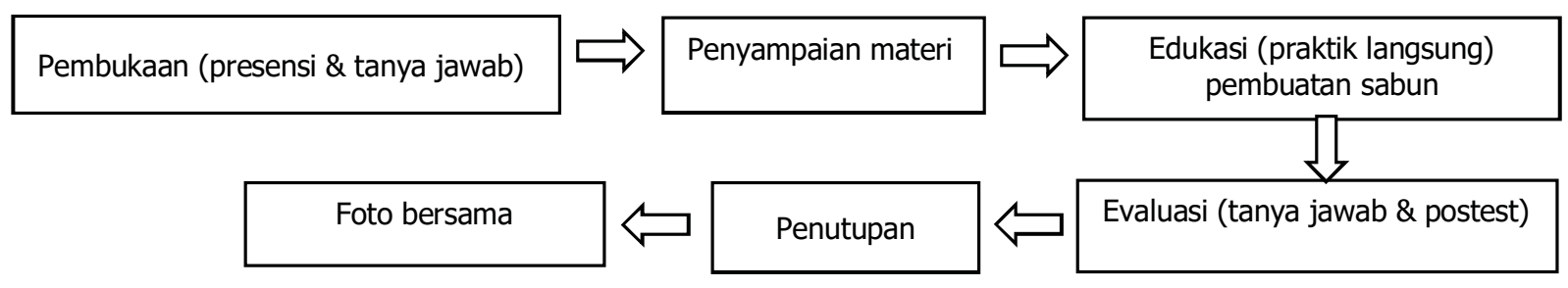

Gambar 2. Langkah-langkah pelaksanaan pengabdian masyarakat

\section{HASIL DAN PEMBAHASAN}

Kegiatan pengabdian masyarakat ini dilaksanakan disalah satu rumah warga di Desa Wates Kecamatan Sumbergempol Kabupaten Tulungagung. Kegiatan pengabdian masyarakat ini mengacu pada permasalahan ibu rumah tangga yaitu penggunaan minyak jelantah. Berdasarkan permasalah yang sudah disampaikan oleh Ketua KRPL, diperlukan edukasi bahaya minyak jelantah dan pemanfaatan kembali minyak jelantah menjadi produk yang bernilai ekonomis. Edukasi ini dilaksanakan pada saat pandemi COVID-19, sehingga peserta yang hadir dibatasi dengan 15 peserta dari anggota KRPL (Kawasan Rumah Pangan Lestari) Rukun Makmur Desa Wates Kecamatan Sumbergempol Kabupaten Tulungagung, yang sebagian besar adalah ibu rumah tangga dan dibantu oleh 2 mahasiswa dan 1 alumni STIKes Karya Putra Bangsa Tulungagung.

Sebelum edukasi dilaksanakan, tim pengabdian melakukan survey kebutuhan warga di Desa Wates Kecamatan Sumbergempol Kabupaten Tulungagung, khususnya anggota KRPL Rukun Makmur pada tanggal 10 Maret 2021. Ibu-ibu KRPL Rukun Makmur Desa Wates Kecamatan Sumbergempol Kabupaten Tulungagung bekerja sebagai petani, pedagang dan ibu rumah tangga dengan jumlah anggota 30 orang. Mayoritas bekerja sebagai petani sekaligus ibu rumah tangga. Pada saat survey, tim pengabdian diterima dengan baik dan dukungan dari Perangkat Desa Wates Kecamatan Sumbergempol Kabupaten Tulungagung. Pada saat survey tim pengabdian dibantu perangkat Desa untuk mencari kebutuhan atau keresahan yang dihadapi warga atau ditemukan di lingkungan Desa Wates Kecamatan Sumbergempol Kabupaten Tulungagung. Tim pengabdian mendapat kesempatan langsung untuk bertemu dan mewawancarai Ketua KRPL Rukun Makmur yaitu Ibu Rupingah. Dari survey ini didapatkan hasil perlunya edukasi bahaya minyak jelantah dan berharap adanya solusi dari minyak jelantah dari limbah rumah tangga di Desa Wates Kecamatan Sumbergempol Kabupaten Tulungagung. Selain itu, tim pengabdian beserta 
ABDIMAS: Jurnal Pengabdian Masyarakat Universitas Merdeka Malang

Volume 7, No 1, February 2022: 84-93

perwakilan KRPL Rukun Makmur yang diwakili oleh Ketua KRPL Rukun Makmur menentukan jadwal kegiatan edukasi dilaksanakan.

Edukasi ini dilaksanakan pada saat pandemic COVID-19, sehingga peserta yang hadir dibatasi dengan 50\% dari jumlah anggota KRPL Rukun Makmur sehingga yang hadir 15 peserta. Antusiasme peserta sangat tinggi, salah satunya dilihat dari jam kedatangan peserta lebih awal dibandingkan dengan jadwal yang sudah ditentukan. Sebelum kegiatan edukasi dilaksanakan, tim pengabdian memastikan para peserta memakai masker atau tidak (tim pengabdian sudah mempersiapkan masker untuk dibagikan), mengingatkan para peserta untuk mencuci tangan terlebih dahulu dan mempersilahkan peserta untuk duduk dan melakukan presensi. Setelah itu, tim pengabdian yang diwakili oleh pemateri memperkenalkan diri dan tim kepada para peserta dan menyampaikan tujuan adanya kegiatan edukasi ini.

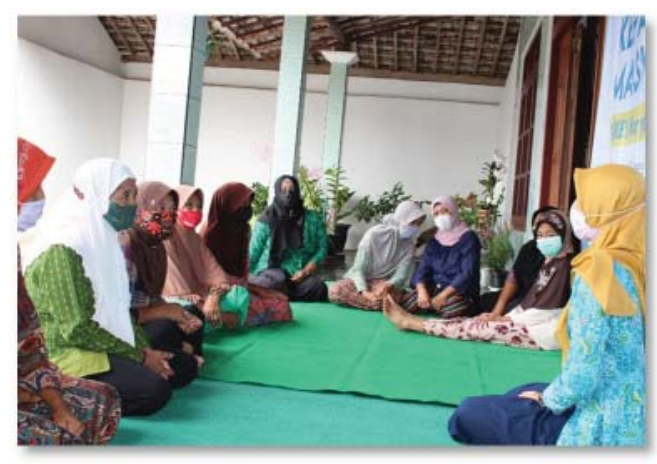

Gambar 3. Penjelasan bahaya minyak jelantah

Pemateri menyampaikan materi (Gambar 3) tentang edukasi dari bahaya minyak jelantah. Pemateri memberikan 5 inti materi, yaitu: (1) Perbedaan minyak goreng dan minyak jelantah; (2) Ambang batas yang perlu diperhatikan dalam menggunakan minyak goreng; (3) Pemilihan minyak goreng yang baik dilihat dari berbagai mutu (fisik dan kimia); (4) Bahaya minyak jelantah; (5) Cara menanggulangi minyak jelantah yaitu dengan pemanfaatkan kembali limbah; (6) Produk dari minyak jelantah yang bernilai ekonomis.

Menurut Muchtadi (2009) minyak goreng adalah hasil pemurnian dari minyak nabati yang digunakan untuk menggoreng makanan atau bahan pangan. Jika, minyak goreng yang baru digunakan untuk menggoreng makanan secara berulang-ulang dengan minyak goreng yang sama disebut dengan minyak jelantah. Minyak jelantah yaitu minyak goreng yang sudah mengalami perubahan struktur fisik dan kimianya. Struktur kimia dari minyak goreng akan rusak atau mengalami oksidasi dari asam lemak tak jenuh yang menjadi gugus peroksida (Nainggolan dan Anna, 2016). Gugus peroksida ini yang sangat berbahaya bagi kesehatan tubuh, yang biasa dikenal dengan radikal bebas yang bersifat racun (Li et al., 2015). Hasil oksidasi dari asam lemak yaitu berupa aldehid, alkohol dan keton, yang menyebabkan minyak jelantah mempunyai bau yang khas dan warna akan berubah menjadi coklat kehitaman (Ketaren, 2008). Oleh sebab itu, minyak jelantah sangat tidak dianjurkan untuk tidak digunakan dalam menggoreng makanan.

Minyak goreng yang baik selain dilihat dari segi mutu fisik dan kimianya, juga dapat dilihat dari segi penggunaannya. Minyak goreng yang baik digunakan kurang dari 2 kali penggorengan, jika lebih dari 2 kali penggorengan dengan minyak goreng yang sama sudah termasuk ke dalam minyak jelantah. Selain itu, yang harus diperhatikan adalah dari segi pemanasannya. Pemanasan minyak goreng yang 


\section{Education on making natural herbal soap made from waste cooking oil}

Rahma Diyan Martha, Ika Rachutami, Danar Danar

melebihi standarnya akan mempercepat proses oksidasi. Standarisasi proses pemanasan minyak goreng yang digunakan untuk menggoreng makanan yaitu rentang $95-120{ }^{\circ} \mathrm{C}$ (Shafiq, 2007).

Pemilihan minyak goreng dapat dilihat dari segi karakteristik kimia yang meliputi jumlah dan komposisi asam lemak, dan karakteristik fisik seperti warna, bau, viskositas, titik didih dan bobot jenis. Sehingga pada saat memutuskan untuk membeli minyak goreng, sebaiknya diperhatikan dulu dari segi fisiknya yang berupa warna. Minyak goreng yang baik memiliki warna kuning jernih, tidak mengendap atau memiliki kekentalan yang sedang.

Kebiasaan di masyarakat khususnya anggota KRPL Rukun Makmur masih memakasi minyak goreng yang sama secara berulang-ulang untuk menggoreng makanan. Mereka punya alasan sendiri untuk tetap memakai minyak jelantah yaitu dapat menghemat biaya, dan selama dilihat secara fisik minyak goreng tersebut masih terlihat baik (jernih) yang baru dipakai 1-2 kali penggorengan. Selain itu, dari segi harga minyak jelantah lebih murah dibandingkan dengan minyak kemasan yang baru. Namun, para ibu-ibu KRPL Rukun Makmur tidak mempertimbangkan terkait kesehatan atau dampak yang didapat setelah mengkonsumsi makanan hasil penggorengan dengan minyak jelantah. Makanan hasil penggorengan dengan minyak jelatah jika dikonsumsi dapat memberikan dampak yang berbahaya bagi tubuh seperti penyakit jantung.

Menurut Weldi (2010) minyak jelantah yang berwarna kecoklatan umumnya dapat dijernihkan kembali dengan proses filtrasi, sehingga jika dilihat secara fisik seperti minyak goreng baru, namun kandungannya tetap mengalami kerusakan sehingga tidak aman bagi tubuh kita. Untuk itu, perlu adanya inovasi dari minyak jelantah yaitu dengan cara memanfaatkan kembali minyak jelantah, sebagai dasar pembuatan produk. Salah satu produk yang dapat dihasilkan dari minyak jelantah yaitu sabun.

Sabun berbahan dasar dari limbah minyak jelantah adalah salah satu inovasi baru di kalangan ibu-ibu KRPL Rukun Makmur. Hal tersebut menambah antusiasme para peserta untuk mengikuti edukasi pembuatan sabun. Pembuatannya tidak membutuhkan waktu yang lama dan mudah untuk dipraktikkan, karena menggunakan bahan-bahan yang mudah dijumpai. Sabun minyak jelantah disarankan hanya untuk mencuci kain atau lap, tidak dianjurkan untuk diaplikasikan di kulit atau tubuh, khususnya wajah. Karena, pembuatan sabun dari minyak jelantah ini termasuk ke dalam home industry, yang belum mempunyai standar mutu seperti di industri besar. Standar mutu yang dimaksud disini adalah standar mutu fisik dan kimia, berskala SNI.

Penyampaian materi tersebut dengan metode ceramah serta tanya jawab dan pembagian pretest kepada para peserta. Pembagian pretest disini bertujuan untuk mengetahui sejauh mana peserta mengetahui tentang bahaya minyak jelantah dan pemanfaatannya, sehingga pemateri bisa mengetahui ada permasalahan atau tidak di kalangan anggota KRPL Rukun Makmur Desa Wates Kecamatan Sumbergempol Kabupaten Tulungagung. Dari hasil pretest yang sudah diisi oleh peserta, dapat diketahui bahwa kurangnya pengetahuan tentang batas penggunaan minyak goreng, pemilihan minyak goreng yang baik, bahaya minyak jelantah dan dampak yang ditimbulkan menggunakan minyak goreng yang sama untuk menggoreng makanan, serta inovasi baru berupa produk yang berbahan dasar minyak jelantah. Para peserta memiliki alasan tersendiri kenapa masih menggunakan minyak goreng yang sama selama warna dari minyak goreng tersebut masih bagus dan sayang untuk dibuang. Dari sini, pemateri menjelaskan bahaya dan dampak yang ditimbulkan setelah mengkonsumsi hasil penggorengan akan berdampak pada kesehatan tubuh. Pemateri juga menyampaikan bahwa limbah minyak goreng dapat digunakan kembali atau dimanfaatkan menjadi produk yang bernilai ekonomis. Para peserta sangat antusiasme dengan pembuatan produk dari minyak jelantah. Setelah sesi pertama selesai, dilanjutkan dengan sesi kedua yaitu edukasi pembuatan sabun dari minyak jelantah (Gambar 4). 
ABDIMAS: Jurnal Pengabdian Masyarakat Universitas Merdeka Malang

Volume 7, No 1, February 2022: 84-93
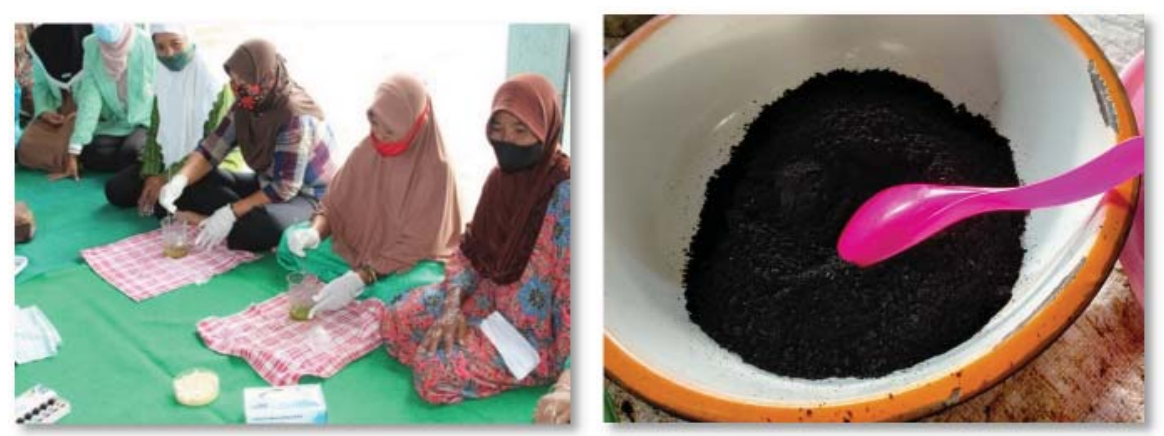

Gambar 4. Pembuatan sabun minyak jelantah

Gambar 5. Arang aktif dari bonggol jagung

Pembuatan sabun dari minyak jelantah merupakan alternatif pemanfaatan limbah minyak jelantah yang mudah dipraktikkan. Proses pembuatan sabun dari minyak jelantah berjalan dalam 3 tahapan. Tahapan pertama yaitu menyiapkan bahan dan alat yang digunakan, untuk bahannya adalah minyak jelantah, $\mathrm{NaOH}$, arang aktif, ekstrak herbal (serai dan daun pandan) dan pewangi (sesuai selera). Alat-alat yang digunakan dalam pembuatan sabun adalah wadah (beaker glass), pengaduk (spatula), gelas ukur, sarung tangan, saringan, timbangan dan cetakan sabun (bentuk sesuai selera).

Tahapan kedua dalam pembuatan sabun yaitu terlebih dahulu minyak jelantah dimurnikan dengan arang aktif (arang kayu). Arang aktif yang digunakan pada kegiatan ini adalah arang aktif yang bersumber dari bonggol jagung yang sudah dibuat serbuk (Gambar 5). Pemilihan bonggol jagung sebagai sumber arang didasarkan melimpahnya limbah bonggol jagung di Desa Wates Sumbergempol Tulungagung. Arang aktif yang ditambahkan berfungsi mendegradasi warna minyak jelantah menjadi lebih jernih dan menurunkan kadar asam lemak bebas (Free Fatty Acid) (Hidayati, 2016). Selain itu, arang aktif yang ditambahkan juga berperan sebagai adsorben bau sehingga minyak jelantah menjadi tidak berbau (Erawati \& Fernanda, 2018). Pemurnian dengan arang aktif dilakukan selama 24 jam atau tergantung dengan jumlah dan warna dari minyak jelantah. Semakin banyak jumlah dan warna yang kecoklatan atau gelap pada minyak jelantah otomatis membutuhkan waktu yang lama. Minyak jelantah yang sudah murni atau jernih kemudian disaring dengan kain bersih.

Tahapan terakhir, hasil saringan ditambahkan dengan ekstrak herbal sambil diaduk. Setelah homogen, campuran tersebut ditambahkan dengan $\mathrm{NaOH}$ hingga mengental. Proses pencampuran minyak jelantah yang sudah dilakukan perlakuan ini dengan $\mathrm{NaOH}$ terjadi reaksi penyabunan (Gambar 6).

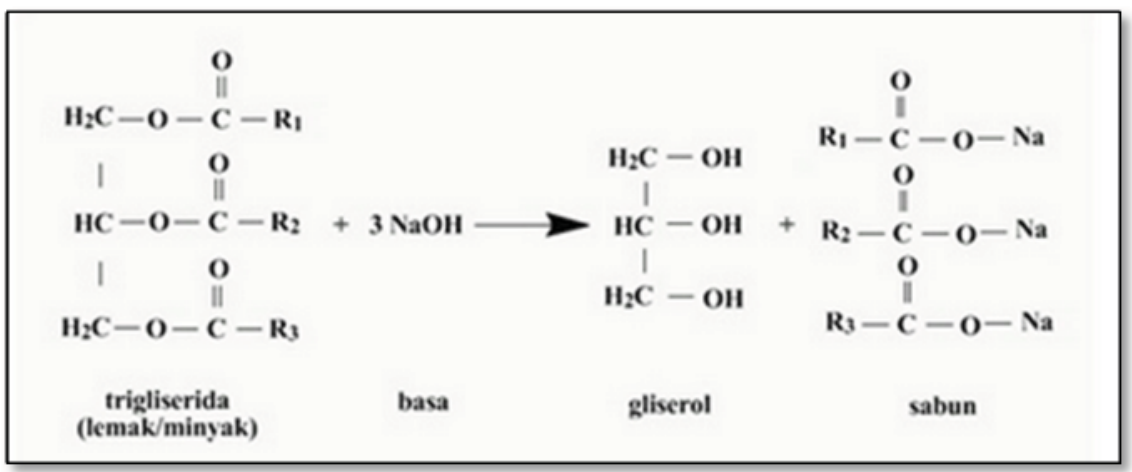

Gambar 6. Reaksi penyabunan antara minyak jelantah dengan $\mathrm{NaOH}$ 
Pencampuran minyak jelantah dengan $\mathrm{NaOH}$ disarankan ditempatkan di wadah yang berasal dari kaca seperti gelas kaca. Pada proses ini dihasilkan panas sehingga penggunaan wadah yang berasal dari plastik dapat beresiko terjadi reaksi campuran dengan wadah dan untuk mendapatkan sabun yang lebih wangi bisa ditambahkan dengan pewangi (fragrance oil) sesuai selera. Pewangi yang digunakan pada kegiatan ini adalah pewangi alami yang berasal dari ekstrak tanaman. Contoh ekstrak tanaman yang digunakan adalah ekstrak daun pandan, ekstrak jeruk, dan ekstrak sereh. Hal ini tentu menambah nilai tambah dari sabun yang diperoleh. Campuran yang mulai mengental kemudian siap dicetak sesuai keinginan atau selera (Gambar 7) dan didapatkan sabun nabati.

Setelah kegiatan praktik pembuatan sabun, pemateri memberikan posttest yang bertujuan untuk mengetahui sejauh mana pengetahuan peserta setelah mengikuti edukasi pembuatan sabun dari minyak jelantah. Bagi peserta yang tidak bisa menulis atau membaca, pengisian posttest dibantu oleh mahasiswa STIKes Karya Putra Bangsa, dengan cara dibacakan dan peserta menjawab pertanyaan yang disampaikan kemudian mahasiswa menuliskan jawaban tersebut di lembar posttest (Gambar 8).

Di akhir kegiatan pengabdian masyarakat ini adalah sesi penutup. Sesi penutup disampaikan oleh pemateri, yang menyampaikan ucapan terima kasih kepada pihak desa (perangkat) dan khususnya anggota KRPL Rukun Makmur, yang sudah mendukung dan berpartisipasi dalam kegiatan pengabdian masyarakat ini. Selain itu, pematerijuga menyampaikan harapannya kepada anggota KRPL Rukun Makmur yang mengikuti edukasi minyak jelantah ini dapat mulai diterapkan di kehidupan sehari-hari. Selain itu, pemateri memberikan kesempatan bagi perwakilan anggota KRPL Rukun Makmur untuk menyampaikan harapan setelah mengikuti kegiatan pengabdian masyarakat ini. Perwakilan dari anggota KRPL Rukun Makmur berharap tahun depan ada pengabdian masyarakat lagi dengan inovasi yang lain. Setelah itu, ada sesi foto bersama seluruh peserta dan tim pengabdian masyarakat (Gambar 9). Foto bersama ini dapat digunakan sebagai kenang-kenangan dan juga bukti bahwa pernah dilakukan pengabdian masyarakat di Desa Wates Kecamatan Sumbergempol Kabupaten Tulungagung.
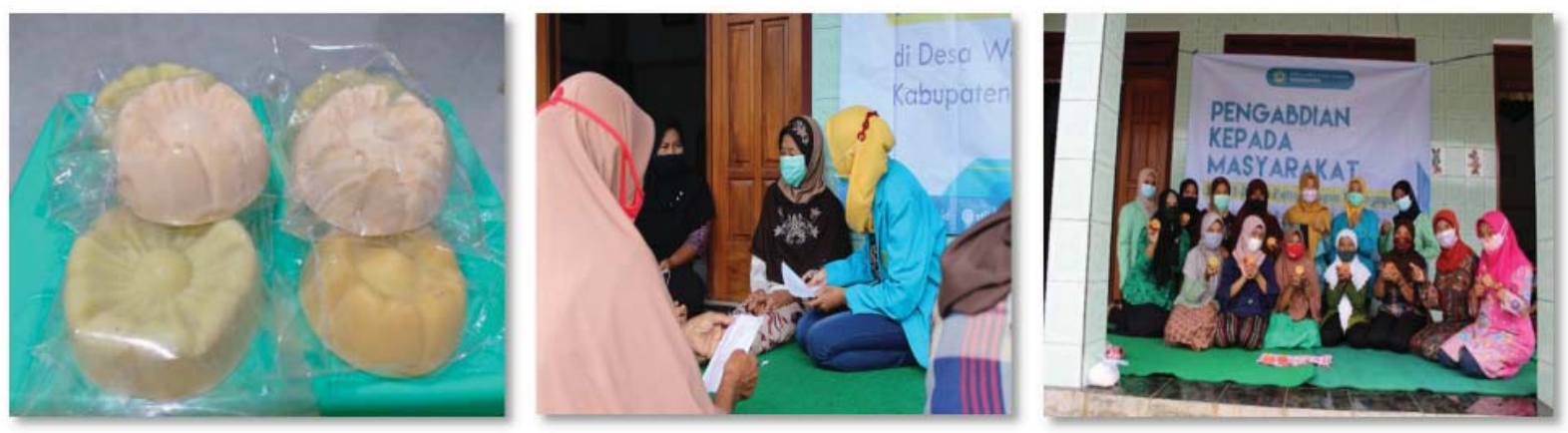

Gambar 7. Sabun minyak jelantah hasil pelatihan

Gambar 8. Pengisian postest

Gambar 9. Foto bersama peserta

Tabel 1 merupakan hasil dari edukasi bahaya minyak jelantah dan pemanfaatannya menjadi produk sabun yang bernilai ekonomis.

Dari hasil evaluasi (Tabel 1) terlihat bahwa untuk pertanyaan nomor 1 terjadi peningkatan persentase setelah adanya pelatihan terkait bahaya minyak jelantah. Peningkatan menjadi $100 \%$ yang artinya bahwa peserta sudah memahami bahaya minyak jelantah, jika kita mengkonsumsi makanan hasil penggorengan dari minyak jelantah. Untuk pertanyaan nomor 2 terjadi peningkatan persentase, meskipun tidak terlalu signifikan karena peserta sudah tahu setelah pelatihan ini mejadi lebih tahu dan 
ABDIMAS: Jurnal Pengabdian Masyarakat Universitas Merdeka Malang

Volume 7, No 1, February 2022: 84-93

memahami, jika minyak goreng boleh digunakan untuk menggoreng lagi maksimal 2 kali penggorengan. Peserta ada yang mempertimbangkan minyak goreng tersebut untuk memakainya sesuai saran dari pemateri, namun juga ada yang memilih hanya sekali penggorengan. Dari peserta yang masih memilih menggunakan minyak goreng lebih dari 2 kali, karena mereka mempunyai alasan sendiri salah satunya adalah faktor ekonomi. Dari pertanyaan nomor 3, terjadi peningkatan persentase terkait pembuangan minyak jelantah setelah adanya pelatihan ini para peserta tidak membuang minyakjelantah sembarangan dan akan dimanfaatkan. Pertanyaan nomor 4, setelah adanya pelatihan ini ada peningkatan 100\% terkait manfaat lain dari minyak jelantah yang sebelumnya, minyak jelantah digunakan untuk membakar sampah pengganti dari minyak tanah, setelah adanya edukasi ini ada manfaat lain, untuk membuat produk yang bernilai ekonomis dan mudah untuk dipraktikkan yaitu sabun dari minyak jelantah. Pertanyaan nomor 5 , terkait cara pembuatan sabun meningkat $100 \%$ setelah adanya pelatihan. Para peserta sebelumnya tidak tau manfaat lain dari minyak jelantah, sampai dengan pembuatannya. Dengan adanya praktik langsung cara pembuatan sabun dari minyak jelantah sangat mengundang antusiasme peserta. Dari pertanyaan nomor 6, dapat disimpulkan bahwa pelatihan atau edukasi pembuatan sabun dari minyak jelantah ini sangat bermanfaat untuk mereka.

Tabel 1. Pemahaman peserta mengenai pembuatan sabun minyak jelantah

\begin{tabular}{|c|c|c|c|c|}
\hline \multirow{3}{*}{ Pertanyaan } & \multicolumn{4}{|c|}{ Persentase (\%) Jawaban Pertanyaan } \\
\hline & \multicolumn{2}{|c|}{ Sebelum Pelatihan } & \multicolumn{2}{|c|}{ Sesudah Pelatihan } \\
\hline & Ya & Tidak & $\mathbf{Y a}$ & Tidak \\
\hline Apakah Anda mengetahui bahaya minyak jelantah? & 30 & 70 & 100 & 0 \\
\hline $\begin{array}{l}\text { Apakah Anda menggunakan minyak jelantah untuk setiap } \\
\text { penggorengan? }\end{array}$ & 60 & 40 & 20 & 80 \\
\hline $\begin{array}{l}\text { Apakah Anda membuang minyak jelantah setelah di- } \\
\text { pakai? }\end{array}$ & 70 & 30 & 10 & 90 \\
\hline Apakah Anda mengetahui manfaat lain minyak jelantah? & 40 & 60 & 100 & 0 \\
\hline Apakah Anda mengetahui cara pembuatan sabun? & 0 & 100 & 100 & 0 \\
\hline $\begin{array}{l}\text { Apakah Anda mendapatkan manfaat dari penyuluhan dan } \\
\text { edukasi ini? }\end{array}$ & 100 & 0 & 100 & 0 \\
\hline
\end{tabular}

\section{SIMPULAN DAN SARAN}

Kesimpulan dari pengabdian kepada masyarakat yang telah dilakukan di Desa Wates Kecamatan Sumbergempol Kabupaten Tulungagung adalah sebagai berikut: (1) Ibu rumah tangga di Desa Wates mendapatkan pengetahuan tentang bahaya minyak jelantah; Edukasi pembuatan produk yang bernilai ekonomis yaitu sabun dari minyak jelantah dapat dilakukan dengan baik dan disambut antusiasme yang tinggi oleh para peserta; (3) Peserta mempunyai ketrampilan dalam pembuatan sabun.

Kegiatan pengabdian masyarakat ini mempunyai bebeapa kendala dan keterbatasan, diantaranya kegiatan dilaksanakan pada saat pandemi COVID-19, sehingga peserta dibatasi dan tetap mematuhi protocol kesehatan. Program pengabdian ini diharapkan ada tindaklanjut seterusnya dari tahun ke tahun dengan inofasi yang lain. Dengan kata lain dengan tema yang sama yaitu memanfaatkan limbah rumah tangga menjadi suatau produk yang bernilai ekonomis. Kegiatan pelatihan pembuatan sabun ini diharapkan juga dapat disosialisasikan kembali kepada para peserta yang lain, yang belum mendapatkan kesempatan melihat langsung pembuatan sabun dari minyak jelantah. 


\section{UCAPAN TERIMA KASIH}

Ucapan terimakasih disampaikan kepada STIKes Karya Putra Bangsa Tulungagung dan segenap warga Desa Wates Sumbergempol (khususnya yang terlibat langsung dalam kegiatan) sehingga dapat terlaksana dengan baik.

\section{DAFTAR PUSTAKA}

Erawati, E., \& Fernando, A. (2018). Pengaruh jenis aktivator dan ukuran karbon aktif terhadap pembuatan adsorbent dari serbik gergaji kayu sengon (Paraserianthes Falcataria). Jurnal Integrasi Proses, (7), 58-66. http://doi.org/10.36055/jip.v7i2.3808

Hidayati, F. C. (2016). Pemurnian minyak goreng bekas pakai (jelantah) dengan menggunakan arang bonggol jagung. JIPF (Jurnal Ilmu Pendidikan Fisika), (1), 67-70. http://doi.org/10.26737/jipf.v1i2.67

Kusumaningtyas, R. D., Qudus, N., Putri, R. D. A., \& Kusumawardani, R. (2018). Penerapan teknologi pengolahan limbah minyak goreng bekas menjadi sabun cuci piring untuk pengendalian pencemaran dan pemberdayaan masyarakat. Abdimas. 22(2), 201-208.

Li S, Tan H. Y., Wang N, Zhang Z. J., Lao L, Wong C.W., \& Feng Y. (2015). The role of oxidative stress and antioxidant in liver disease. International Journal of Molecular Science, 16(11), 26087-124. https://doi.org/10.3390/ijms161125942

Ketaren, S. (2008). Minyak dan lemak pangan. Universitas Indonesia Press.

Nane, E., Immanuel, G. S., \& Wardani, M. K. (2014). Pemanfaatan jelantah sebagai bahan alternatif pembuatan lilin. Inovasi dan Pembangunan-Jurnal Kelitbangan, 2(02).

Nainggolan, B. S., \& Anna, J. (2016). Uji kelayakan minyak goreng curah dan kemasan yang digunakan menggoreng secara berulang. Jurnal Pendidikan Kimia, 8(01), 45-57. https://doi.org/10.24114/jpkim.v8i1.4424

Noriko, N., Elfidasari, D., Perdana, A. T., Wulandari, N., \& Wijayanti, W. (2012). Analisis penggunaan dan syarat mutu minyak goreng pada penjaja makanan di food court UAl. Al Azhar Indonesia Seri Saind dan Teknologi, 1(3), 147-154. http://doi.org/10.36722/sst.v1i3.52

Putra, G., Wartini, N. M., Wrasiati, L. P., \& Yoga, I. W. G. S. (2016). Penyuluhan dan pelatihan pembuatan sabun aroma terapi dari minyak kelapa pada KWT "Wiguna Mekar" di Desa Angkah, Kecamatan Selemadeg Barat, Kabupaten Tabanan. Program Studi Teknologi Industri Pertanian Fakultas Teknologi Pertanian. Universitas Udayana.

Pujiati, A., \& Retariandalas, R. (2019). Utilization of domestic waste for bar soap and enzyme cleanner (ecoenzyme)[pemanfaatan limbah rumah tangga untuk pembuatan sabun batang dan pembersih serbaguna (ecoenzym)]. Proceeding of Community Development, 2, 777-781. https://doi.org/10.30874/comdev.2018.489

Rahayu, S., Aliyah, H., \& Tukasno. (2020). Pemanfaatan minyak jelatah dan arang kayu untuk membuat sabun daur ulang. Jurnal Pengabdian KITA, 3(1).

Suroso, A. S. (2013). Kualitas minyak goreng habis pakai ditinjau dari bilangan peroksida, bilangan asam, dan kadar air. Jurnal Kefarmasian Indonesia, 3(2), 77-88.

Sutiah, S., Firdausi, K. S., \& Budi, W. S. (2008). Studi kualitas minyak goreng dengan parameter viskositas dan indeks bias. Berkala Fisika, 11(2), 53-58.

Wijaya, J., Rohanah, A., \& Rindang, A. (2014). Pengolahan minyak jelantah menjadi sabun batang dengan ekstrak kunyit, lidah buaya, dan pepaya. Jurnal Rekayasa Pangan dan Pertanian, 2(4), 139-145. 